\title{
Taxonomic assessment of the Oxytropis species from South-East of Kazakhstan
}

\author{
S. Almerekova ${ }^{1,2}$, S. Abugalieva ${ }^{1,2} \otimes$, N. Mukhitdinov ${ }^{2}$ \\ ${ }^{1}$ Institute of Plant Biology and Biotechnology, Almaty, Kazakhstan \\ ${ }^{2}$ Al-Farabi Kazakh National University, Almaty, Kazakhstan
}

\begin{abstract}
The genus Oxytropis DC. is one of the largest genera in the Fabaceae family. The most plant species belonging to the Oxytropis genus have an important medicinal value. Currently the botanical taxonomy of the genus is complicated due to existence of many subgenera and sections that developed based on morphological traits. Also, in the literature there is luck of knowledge on phylogeny of Oxytropis species from Central Asian region. Therefore, the purpose of the present study was the clarification of taxonomic relationship of two Oxytropis species from SouthEast of Kazakhstan (O. almaatensis Bajt. and O. glabra DC.). The study was based on using phylogenetic analysis and haplotype network assessment based on sequences ITS (internal transcribed spacers), which is DNA marker of nuclear genome. Plant materials of $O$. almaatensis were collected from 2 populations in two neighboring Gorges in Trans Ili Alatau Mountains, O. glabra plant material was obtained from Herbarium of the Department of Biodiversity and Bioresources, al-Farabi Kazakh National University. Based on DNA sequences of ITS the phylogenetic and network relationships were investigated by using Neighbor Joining and Median Joining methods, respectively. The nucleotide sequences of ITS of $O$. almaatensis and O. glabra were aligned with sequences of 29 Oxytropis references found in the NCBI database. Out of the 601 aligned positions of ITS 33 (5.6\%) sites were found to be polymorphic nucleotides and used in evaluation of the genetic relationship of species. Constructed MJ haplotype network showed a very high congruence with the NJ phylogenetic tree. MJ network provided valuable additional hints in clarification of the taxonomic relationship among species involved in the analysis. In this study phylogenetic NJ tree and MJ network based on the variation of ITS sequences confirmed the monophyletic origin of the genus. The ITS haplotype network suggested that $O$. glabra is very diverse species and possibly played important role in the evolutionary processes of the genus in Central Asian region. The study is additional contribution in the molecular taxonomy of complex Oxytropis genus.
\end{abstract}

Key words: Oxytropis; Oxytropis almaatensis; Oxytropis glabra; DNA barcoding; haplotype network.

HOW TO CITE THIS ARTICLE:

Almerekova S., Abugalieva S., Mukhitdinov N. Taxonomic assessment of the Oxytropis species from South-East of Kazakhstan. Vavilovskii Zhurnal Genetiki i Selektsii = Vavilov Journal of Genetics and Breeding 2018;22(2):285-290. DOI 10.18699/VJ18.362

\section{Таксономическая оценка видов рода Oxytropis из Юго-Восточного Казахстана}

\author{
Ш.С. А^ьмерекова ${ }^{1,2}$, С.И. Абугамиева ${ }^{1,2} \otimes$, \\ Н.М. МухитАинов ${ }^{2}$ \\ ${ }^{1}$ Институт биологии и биотехнологии растений, Алматы, Казахстан
${ }^{2}$ Казахский национальный университет имени аль-Фараби, Алматы,
Казахстан
}

Род Oxytropis DC. является одним из крупнейших родов семейства Fabaceae. Большинство видов растений, принадлежащих к данному роду, имеют важное лекарственное значение. В настоящее время ботаническая систематика рода затруднена в связи с наличием множества подродов и секций. Также в литературе отсутствуют данные о филогенетических взаимосвязях видов Oxytropis из Центральной Азии. В связи с этим целью настоящего исследования было уточнение таксономических взаимоотношений двух видов Oxуtropis из Юго-Восточного Казахстана - O. almaatensis Bajt. и O. glabra DC. Осуществлены филогенетический анализ и оценка сети гаплотипов, базирующиеся на полиморфных последовательностях ITS (internal transcribed spacers), ДНК-маркера ядерного генома. Растительный материал O. almaatensis состоял из двух популяций, собранных в двух соседних ущельях Заилийского Алатау, растительный материал O. glabra был получен из гербарного образца кафедры биоразнообразия и биоресурсов Казахского национального университета имени аль-Фараби. Полученные полиморфные нуклеотидные последовательности ITS были использованы для анализа филогенетических взаимоотношений и сети гаплотипов с помощью методов Neighbor Joining (NJ) и Median Joining (MJ) соответственно. Последовательности ITS O. almaatensis и O. glabra сравнивали с последовательностями 29 образцов Oxytropis, полученными из базы данных GenBank (NCBI). Длина ITS составила 601 п. о., из них 33 (или $5.6 \%$ ) нуклеотида оказались полиморфными, что позволило использовать их в изучении генетического родства видов Oxytropis. В целом построенная сеть гаплотипов MJ позволила выявить высокую степень совпадения с филогенетическим древом NJ. Кроме того, применение MJ сети гаплотипов дало возможность получить ценные дополнительные данные для уточнения таксономических отношений между видами, вовлеченными в анализ. В этом исследовании филогенетическое древо и сеть гаплотипов, построенные на основе вариабельности последовательностей ITS, подтвердили монофилетическое происхождение рода. Построенная сеть гаплотипов позволила предположить, что O. glabra является высоковариабельным видом, который, возможно, играл важную роль в эволюционном процессе рода в Центральной Азии. Исследование внесло дополнительный вклад в изучение молекулярной таксономии рода Oxytropis.

Ключевые слова: Oxytropis; Oxytropis almaatensis; Oxytropis glabra; ДНК-баркодирование; сеть гаплотипов. 
O yytropis DC. with approximately 450 species, most of which are hairy perennial plants, is one of the largest genera in the family Fabaceae (Malyshev, 2008a). Oxytropis species are well distributed in Central Asia and rich in endemics, especially in mountain systems of Mongolian Altay, Tien Shan, Nanshan and Himalayas (Grubov, 2003). Grubov (2003) reported that Central Asia, along with West Asia, is the most important center of the speciation of genus Oxytropis. In Central Asia the genus consists of all the six subgenera and sixteen sections (Grubov, 2003). In northern Tien Shan the species composition of the genus Oxytropis has been studied by Abdulina (1978). Morphological studies of the species found in the northern Tien Shan region were carried out, the most convenient traits for diagnostics of taxa were identified, areas of endemic species and maps of their distribution have been specified (Abdulina, 1978). According to Malyshev (2008b) the genus is represented by 6 subgenera and 25 sections. Author clustered 25 sections according to the 50 quantitative alternative morphological characters (Malyshev, 2008b). Due to a large number of Oxytropis species, the taxonomy of this genus is still uncompleted.

In Kazakhstan Oxytropis is represented by 119 species, 36 of which are endemic (Baitenov, 1961). One of those endemic plant species is Oxytropis almaatensis Bajt. listed in the Red Book of Kazakhstan (2014). O. almaatensis is a narrow endemic species of Trans Ili Alatau range which belongs to the Tien Shan Mountains (Baitenov, 1961). According to the literature $O$. almaatensis has potential medicinal benefits. It contains phenol carboxylic acid which is helpful for coronary dilatation and flavonoid ramnazine which has antihypertensive properties (Grudzinskaya et al., 2014).

The DNA barcoding significantly contributed not only in plant species identification but also in the taxonomic relationship of poorly studied species (Techen et al., 2014; Li et al., 2015). Currently, this approach considered as an additional effective tool used in taxonomic studies of the genus Oxytropis (Archambault, Strömvik, 2012; Artyukova, Kozyrenko, 2012; Gao et al., 2013; Lu et al., 2014; Kholina et al., 2016; Tekpinar et al., 2016). For instance, first attempt to clarify taxonomy and biogeography of the genus in Alaska was carried out by Jorgensen (Jorgensen et al., 2003). The use of ITS (internal transcribed spacers) and RAPD (random amplified polymorphic DNA) markers has shown that north-eastern arctic populations in $O$. arctica and $O$. campestris were different from all other studied populations. The genetic subdivision probably reflects a Pleistocene barrier formed by the northern coastal ice shield (Jorgensen et al., 2003). To identify the phylogenetic relationship of Turkish Oxytropis species the trnL intron, $t r n \mathrm{~L}-\mathrm{F}$ intergenic spacer, and $t r n \mathrm{~V}$ intron of chloroplast (cp) DNA were used (Tekpinar et al., 2016). According to Tekpinar (2016) trnL intron was the most variable region. Kholina et al. (2016) assessed phylogenetic relationships of Russian species of Oxytropis from subgenera Oxytropis and Phacoxytropis using trn $\mathrm{H}-p s b \mathrm{~A}, \operatorname{trn} \mathrm{L}-\operatorname{trn} \mathrm{F}$, and $\operatorname{trn} \mathrm{S}-\operatorname{trn} \mathrm{G}$ intergenic spacer regions of chloroplast DNA (cpDNA) and genealogical haplotype network. This helped authors to clarify the phylogenetic relationships of the analysed species and sections within the subgenera.

In Oxytropis taxonomy studies, along with estimated phylogenetic trees, several successful analyses were included haplotype network approach (Artyukova, Kozyrenko, 2012; Kholina et al., 2016, 2017). For instance, the three intergenic spacers $p s b \mathrm{~A}-\operatorname{tr} n \mathrm{H}, \operatorname{trn} \mathrm{L}-\operatorname{trn} \mathrm{F}$, and $\operatorname{trn} \mathrm{S}-\operatorname{trn} \mathrm{G}$ of cpDNA of rare and endemic plant species of Buryatia in four populations from Barguzin and Yeravna depressions were studied (Kholina et al., 2017). Therefore, the assessment of combinations of haplotype network and phylogenetic trees might provide valuable insights into understanding the microevolutionary process for closely related species.

As in the literature there is luck of knowledge on phylogeny of Oxytropis species from Central Asian region, the purpose of the present study was the clarification of taxonomic relationship of two Oxytropis species from South-East of Kazakhstan (O. almaatensis Bajt. and O. glabra DC.). The taxonomic analysis of Oxytropis taxa was relied on using phylogenetic analysis and haplotype network assessment by using the variability of the ITS nucleotide sequences. The study was conducted in the frame of the nation-wide research project DNA barcoding of wild flora of Kazakhstan (Turuspekov, Abugalieva, 2015) that combined efforts of local botanists and geneticists from Biotechnology Research Organizations, Botanical Gardens, National Nature Parks and Reserves as well as project "Informational system for molecular genetic and botanical documentation of wild flora in Kazakhstan". It is another contribution to the description of the genetic variation of wild flora in Kazakhstan (Adams, Turuspekov, 1998; Turuspekov et al., 2002, 2014; Genievskaya et al., 2017).

\section{Materials and methods}

Sample collections and DNA extraction. Samples of leaves from O. almaatensis were collected from 2 populations in two different Gorges in Trans Ili Alatau Mountains (Big Almaty gorge and Small Almaty gorge) in 2015 and 2016, five plant samples from each population were chosen for the genetic analysis. O. glabra plant material was obtained from Herbarium of the Department of Biodiversity and Bioresources, al-Farabi Kazakh National University. For the construction haplotype network and phylogenetic tree ITS sequences were taken from NCBI (https//www.ncbi.nlm.nih.gov/genbank/). DNA was extracted using CTAB protocol (Doyle J.J., Doyle J.L., 1987) and stored at $-20^{\circ} \mathrm{C}$ until use.

DNA amplification and sequencing. PCR fragments were amplified from nuclear ribosomal complex including ITS1 and ITS2 (White et al., 1990). PCR was performed by using Veriti Thermo cycler (Applied Biosystems, Foster City, CA, USA). PCR reaction (total volume $16 \mu \mathrm{l}$ ) contained $4 \mathrm{mM}$ of each dNTP, $6.4 \mathrm{mM}$ of primer mix, 1.6 U of Taq DNA polymerase and $80 \mathrm{ng}$ of total genomic DNA. The entire ITS-1, 5.8S, and ITS-2 region was polymerase chain reaction (PCR)-amplified using primers ITS1nF (5'-AGAAGTCGTAACAAGGTTTC CGTAGG-3') and ITS4nR (5'-TCCTCCGCTTATTGATAT GC-3') with annealing temperature $58^{\circ} \mathrm{C}$ (White et al., 1990). PCR products were run in $1.5 \%$ agarose gel electrophoresis at $80 \mathrm{~V}$ voltage for $40 \mathrm{~min}$. Single bands with expected sizes around $650 \mathrm{bp}$ were cut out from gels and purified using ULTRAPrep ${ }^{\circledR}$ Agarose Gel Extraction Mini Prep Kit (AHN Biotechnologie GmbH, Nordhausen, Germany) according to the protocol provided by the company. Purified DNA amplicons were used for the sequence reactions with forward and reverse primers separately. All reactions were performed 
Haplotypes formed from the analysis of ITS sequences Oxytropis species and the outgroup

\begin{tabular}{|c|c|c|c|c|}
\hline Haplotype & Cluster and haplogroup & Species & GenBank Accession number & Sections \\
\hline Hap_1 & IV & O. revoluta & LM653251 & Atctobia \\
\hline Hap_2 & IV & O. retusa & LM653264 & Orobia \\
\hline \multirow[t]{2}{*}{ Hap_3 } & \multirow[t]{2}{*}{ III } & O. racemosa & HQ199320 & \multirow[t]{2}{*}{ Verticillares } \\
\hline & & O. ochrantha & GQ422820 & \\
\hline Hap_4 & II & O. pilosa & AF121759 & Chrysantha \\
\hline Hap_5 & II & O. pallasii & KM053395 & Chrysantha \\
\hline \multirow[t]{3}{*}{ Hap_6 } & \multirow[t]{3}{*}{ III } & O. oxyphylla & FR839000 & Verticillares \\
\hline & & O. intermedia & LM653257 & \multirow[t]{2}{*}{ Xerobia } \\
\hline & & O. inschanica & HQ199322 & \\
\hline Hap_7 & III & O. microphylla & KP338205 & Polyadena \\
\hline Hap_8 & III & O. maydelliana & HQ176486 & Orobia \\
\hline Hap_9 & III & O. mandshurica & LM653236 & Janthina \\
\hline Hap_10 & III & O. lanata & LM653259 & Verticillares \\
\hline Hap_11 & II & O. kansuensis & KJ143718 & Mesogaea \\
\hline Hap_12 & IV & O. kamtschatica & LM653247 & Atctobia \\
\hline Hap_13 & IV & O. hidakamontana & LM653263 & Atctobia \\
\hline Hap_14 & III & O. filiformis & HQ199321 & Janthina \\
\hline Hap_15 & III & O. evenorum & LM653239 & Orobia \\
\hline Hap_16 & II & O. deflexa & HQ176481 & Mesogaea \\
\hline Hap_17 & III & O. chankaensis & FR839001 & Verticillares \\
\hline Hap_18 & III & O. campestris & HQ176475 & Orobia \\
\hline Hap_19 & III & O. caerulea & GU217599 & Janthina \\
\hline Hap_20 & III & O. borealis & AF121758 & Gloeocephala \\
\hline Hap_21 & II & O. aciphylla & GQ422806 & Lycotriche \\
\hline Hap_22 & 1 & O. glabra & LC213354 & Mesogaea \\
\hline Hap_23 & I & O. glabra & KJ143729 & Mesogaea \\
\hline Hap_24 & 1 & O. glabra, O. glabra & KJ143719, GQ265958 & Mesogaea \\
\hline Hap_25 & I & O. glabra & GQ265961 & Mesogaea \\
\hline Hap_26 & I & O. glabra* & In this study & Mesogaea \\
\hline Hap_27 & I & O. almaatensis* & $\begin{array}{l}\text { MG 282028, } \\
\text { in this study }\end{array}$ & Eumorpha \\
\hline Hap_28 & Outgroup & A. polaris & AF121714 & - \\
\hline Hap_29 & Outgroup & A. mollissimus & AF121719 & - \\
\hline
\end{tabular}

with the BigDye Terminator Cycle Sequencing technology (Applied Biosystems, Foster City, CA, USA). Sequencing was carried out using an ABI 3130 DNA analyzer (Applied Biosystems, ThermoFisher Scientific, Waltham, MA, USA).

Sequence alignment. The ITS sequences were aligned in MEGA 6 (Tamura et al., 2013) by using Neighbor Joining method (NJ) (Saitou, Nei, 1987), the 1000 replication bootstrap test was applied. The sequences of $O$. almaatensis and O. glabra were aligned with other Oxytropis species sequences obtained from NCBI reference database (https//www.ncbi. nlm.nih.gov/genbank/). The ITS sequences of five samples of $O$. almaatensis were identical, consequently one sample was selected for the next analysis and deposited to the NCBI database (MG 282028) (see Table).
Haplotype Network was reconstructed using the Median Joining method (Bandelt et al., 1999) in PopART v.1.7 (Leigh, Bryant, 2015). The aligned sequences were converted into Nexus file format in DNASP v5.10 (Librado, Rozas, 2009) for the operations in the PopART software (version 1.7).

\section{Results}

\section{Phylogenetic tree analyses based on ITS sequences}

The DNA sequences of ITS of $O$. almaatensis and $O$. glabra were aligned with sequences of 29 Oxytropis references extracted from NCBI, and Astragalus polaris and Astragalus mollissimus were chosen as the outgroup taxa. The length of ITS (including ITS1, 5.8S, and ITS2) region for Oxytropis was 


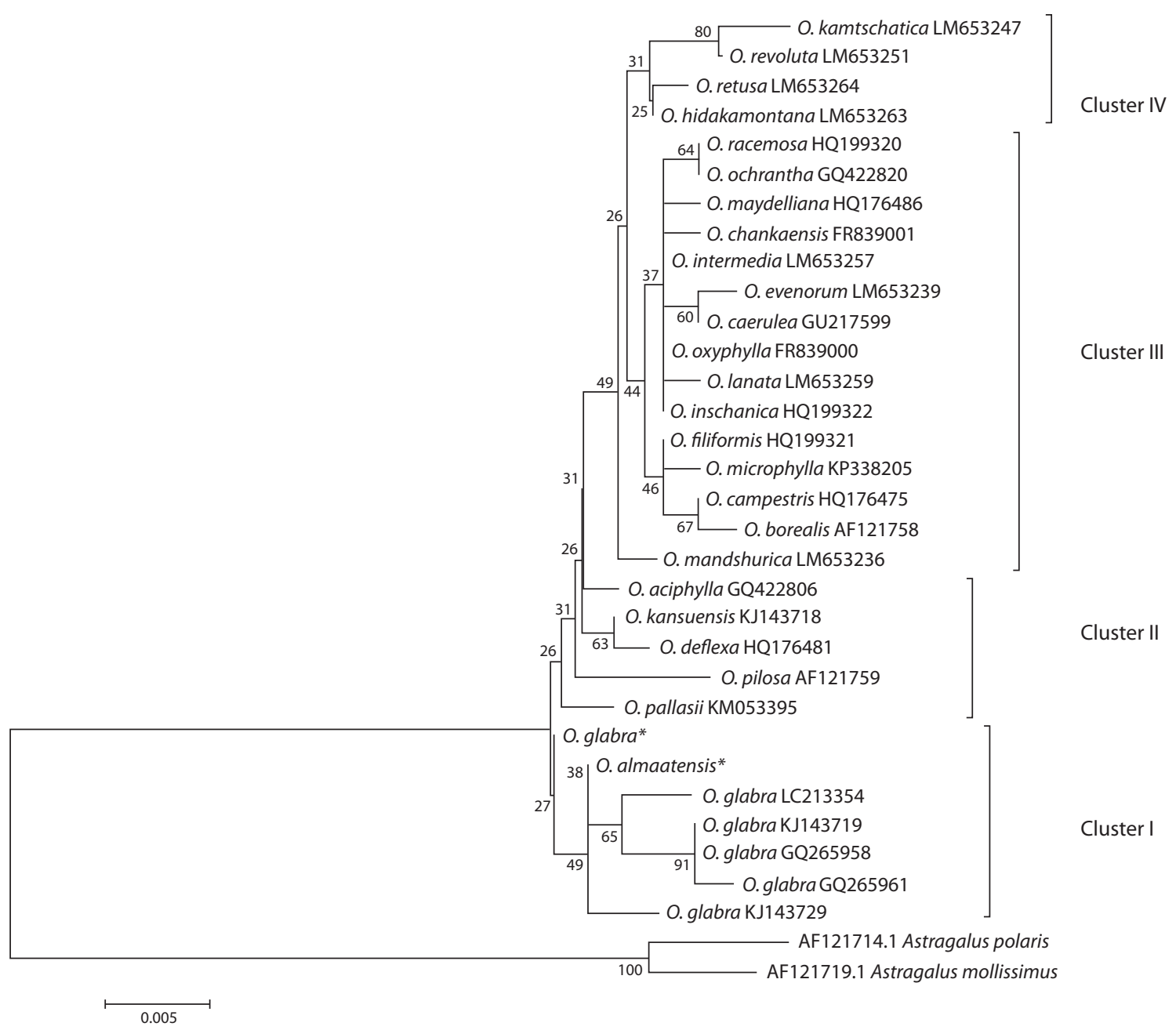

Fig. 1. Neighbor Joining phylogenetic tree reconstructed from the analysis of ITS sequences of Oxytropis and outgroup species.

601 bp. $33(5.6 \%)$ sites out of the 601 aligned positions of ITS were polymorphic without outgroup. Singleton variable sites was 16, parsimony informative sites was 17 .

The ITS nucleotide dataset consisted from $O$. almaatensis, O. glabra sequenced in this study, as well as 29 Oxytropis species and two outgroup species (A. polaris, A. mollissimus) collected from the NCBI database. The NJ tree clustered all Oxytropis accessions into four clusters and separated from the outgroup (Fig. 1). Sequences of O. almaatensis and O. glabra grouped with five references of $O$. glabra from NCBI in Cluster I. The Cluster II grouped together $O$. pallasii, $O$. pilosa, $O$. kansuensis, O. deflexa, and O. aciphylla. The Cluster III was represented by $O$. oxyphylla, $O$. intermedia, $O$. inschanica, O. microphylla, O. maydelliana, O. filiformis, O. evenorum, O. lanata, O. racemosa, O. ochrantha, O. chankaensis, $O$. campestris, $O$. caerulea, $O$. borealis, $O$. mandshurica. The Cluster IV was represented by following species from NCBI: O. kamtschatica, O. hidakamontana, O. revoluta, O. retusa.

\section{Haplotype network analyses based on ITS sequences}

Twenty-nine haplotypes were identified for the ITS region in 33 accessions of Oxytropis genus and outgroup species in the network association analysis (Fig. 2). The results suggested that $\mathrm{Hd}=0.991$ (haplotype diversity), $\pi=0.01498$ (nucleotide diversity), and $k=8.86553$ (average number of nucleotide differences). The 29 haplotypes generated four haplogroups that corresponded to the NJ phylogenetic tree.

The largest haplotype $\mathrm{H} 6$ included $O$. oxyphylla, O. intermedia, $O$. inschanica (from NCBI) in haplogroup III. The next largest haplotype $\mathrm{H} 3$ contained $O$. racemosa, $O$. ochrantha from NCBI from the same haplogroup III. Haplotype 24 included two references of one species O. glabra in haplogroup I. Local species $O$. glabra and $O$. almaatensis generated two different haplotypes, $\mathrm{H} 26$ and $\mathrm{H} 27$, respectively, in haplogroup I (see Fig. 2, Table).

\section{Discussion}

The traditional taxonomy of the genus Oxytropis is still unresolved and has many difficulties. Therefore the application of haplotype network and phylogenetic tree methods using polymorphic molecular markers is essential additional asset molecular taxonomy analyses of complicated genera. In this study phylogenetic NJ tree and MJ network based on the variation of ITS sequences confirmed the monophyletic origin of the genus (see Figs. 1, 2). This result is well in line with previously published results (Archambault, Strömvik, 2012; 


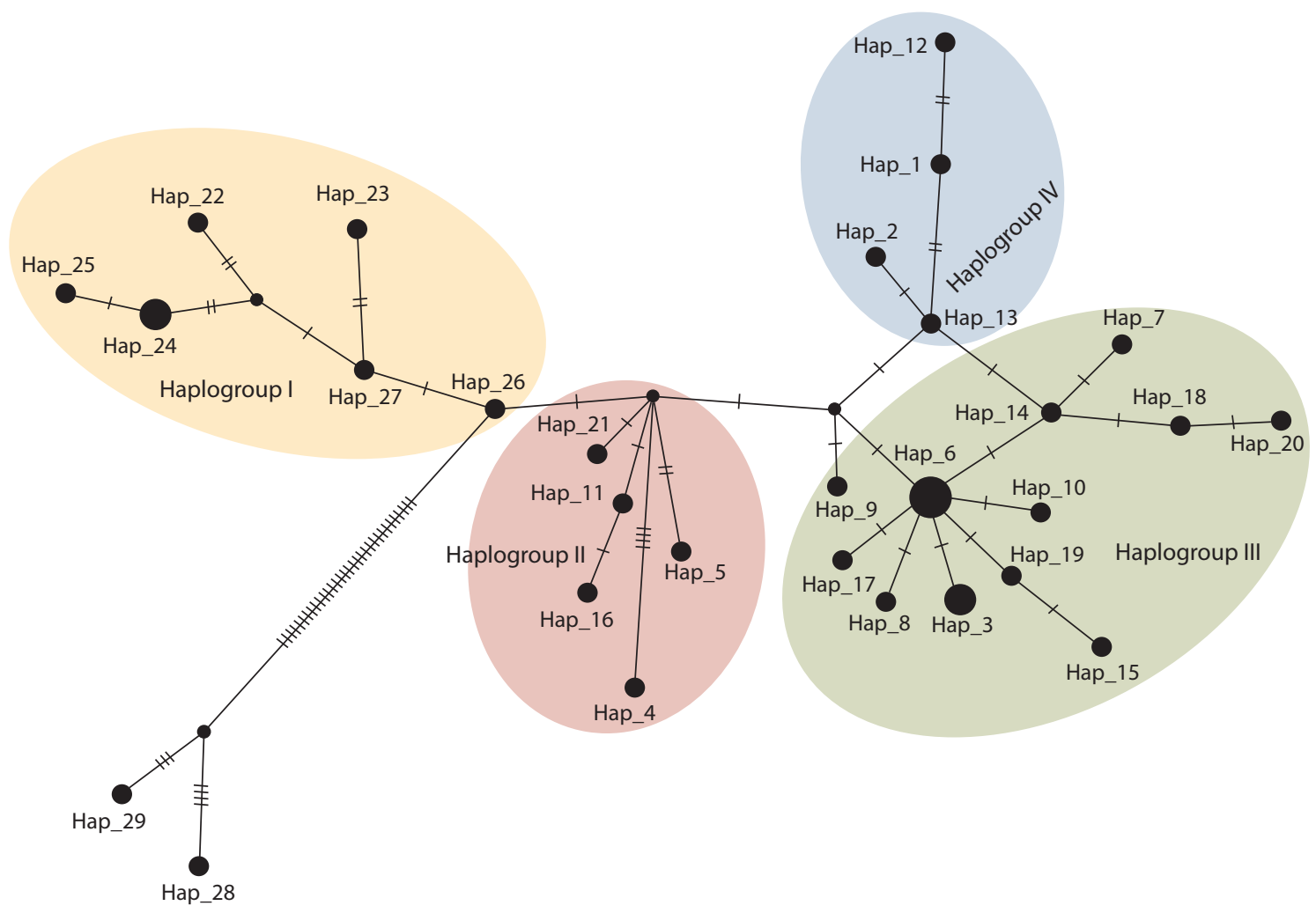

Fig. 2. The Median-joining haplotype network of ITS of Oxytropis and outgroup species.

Gao et al., 2013; Lu et al., 2014). The other important outcome is that the majority of species in this study formed four distinct clusters. The first cluster in the tree and first haplogroup in the network consisted only of two species, O. glabra and O. almaatensis. In general, as shown in previous studies (Archambault, Strömvik, 2012; Kholina et al., 2016) and in present work, the botanical classification is rarely coincided with produced phylogenetic trees, which is further complicate the analyses of the evolutionary processes in the genus Oxytropis.

The phylogenetic tree showed that O. glabra (section Mesogaea) and O. almaatensis (section Eumorpha) are genetically close to each other within the genus Oxytropis. This result is suggesting that there is a possibility of existance of extinct or extant group of relative species that can be evolutionary closely associated with both $O$. glabra and $O$. almaatensis. Therefore, additional studies should be done to clarify this hypothesis.

The ITS network suggested that $O$. glabra is highly polymorphic species and one of their haplotype (Hap 26) is the closest point to two outgroup species of Astragalus (Hap_26 and Hap_29) (see Fig. 2). As both haplotypes, Hap_26 and Hap_27, represented two genetically close species sampled in southeast Kazakhstan, it can be speculated that these regions might associate with one of the centers of diversification for this genus.

The second group of species consisted of five following species - O. pilosa, O. pallasii, O. kansuensis, O. deflexa, and $O$. aciphylla. In previously published articles the majority of these species was often clustered together with O. glabra (Archambault, Strömvik, 2012; Artyukova, Kozyrenko, 2012;
Kholina et al., 2016). In this study, the haplotype network separated these two groups as all five species of the second cluster were bound to the same median vector ( $m v$ ) (see Fig. 2). Thus, it is a possibility that species may have the same extinct or extant predecessor, which is genetically close to $O$. kansuensis, $O$. deflexa, and $O$. aciphylla. Most populated groups of Oxytropis species formed the third cluster (haplogroup III) that has a connection to the $O$. mandshurica via a common $m v$ in the network (Fig. 2). Similarly, O. mandshurica (Hap_9) using the same $m v$ was also connected to haplogroup IV, represented by four Far East species (Kholina et al., 2016). It is interesting that the network is suggesting a close genetic relationship between $O$. filiformis (haplogroup III) and $O$. hidakamontana (haplogroup IV) despite their clasterization in different sub clades (see Fig. 2).

In general, the constructed haplotype network showed a very high congruence with the NJ phylogenetic tree. As generated NJ dendrogram showed a relatively low bootstrap value indices; the network provided valuable additional hints in clarification of the taxonomic relationship among species involved in the analysis. The study is another contribution in the molecular taxonomy of complex Oxytropis genus.

\section{Acknowledgments}

The authors would like to acknowledge the funding of the grant AP05131621 from the Ministry of Education and Sciences of the Republic of Kazakhstan.

\section{Conflict of interest}

The authors declare no conflict of interest. 


\section{References}

Abdulina S.A. Endemic species of the genus Oxytropis DC. in Northern Tien Shan. Bull. Acad. Sci. Kazakh SSR. 1978:66-71.

Adams R.P., Turuspekov Y. Taxonomic reassessment of some Central Asian and Himalayan scale-leaved taxa of Juniperus (Cupressaceae) supported by random amplification of polymorphic DNA. Taxon. 1998; $47: 75-84$.

Archambault A., Strömvik M.V. Evolutionary relationships in Oxytropis species, as estimated from the nuclear ribosomal internal transcribed spacer (ITS) sequences point to multiple expansions into the Arctic. Botany. 2012;90:770-779. DOI 10.1139/b2012-023.

Artyukova E.V., Kozyrenko M.M. Phylogenetic relationships of $O x y$ tropis chankaensis Jurtz. and Oxytropis oxyphylla (Pall.) DC. (Fabaceae) inferred from the data of sequencing of the ITS region of the nuclear ribosomal DNA operon and intergenic spacers of the chloroplast genome. Genetika. 2012;48:186-193. DOI 10.1134/ S1022795411110032.

Baitenov M.S. Oxytropis almaatensis Bajt. sp. nova. Flora Kazahstana. T. V. [Flora of Kazakhstan. Vol. V]. Ed. N.V. Pavlov. Alma-Ata: Akademija Nauk Kazakhskoy SSR, 1961;330-410. (in Russian)

Bandelt H.J., Forster P., Röhl A. Median-joining networks for inferring intraspecific phylogenies. Mol. Biol. Evol. 1999;16(1):37-48.

Doyle J.J., Doyle J.L. A rapid DNA isolation procedure for small quantities of fresh leaf tissue. Phytochem. Bull. 1987;19:11-15.

Gao L., Lu P., Jin F., Enhebayaer E., Gao J. TrnL-F sequences analysis and molecular phylogeny of 10 species of Oxytropis. Acta Botanica Boreali-Occidentalia Sinica. 2013;2:266-271.

Genievskaya Y., Abugalieva S., Zhubanysheva A., Turuspekov Y. Morphological description and DNA barcoding study of sand rice (Agriophyllum squarrosum, Chenopodiaceae) collected in Kazakhstan. BMC Plant Biology. 2017;17(Suppl.1):177. DOI 10.1186/ s12870-017-1132-1

Grubov V.I. Plants of Central Asia - Plant Collection from China and Mongolia. Vol. 8b. Legumes, Genus Oxytropis. Enfield Taylor \& Francis, 2003.

Grudzinskaya L.M., Gemedzhieva N.G., Nelina N.V., Karzhaubekova J.J. Annotirovannyj spisok lekarstvennyh rastenij Kazahstana: Spravochnoe izdanie [Annotated checklist of medicinal plants in Kazakhstan: a reference book]. Almaty, 2014. (in Russian)

Jorgensen J.L., Stehlik I., Brochmann C., Conti E. Implications of ITS sequences and RAPD markers for the taxonomy and biogeography of the Oxytropis campestris and O. arctica (Fabaceae) complexes in Alaska. Am. J. Bot. 2003;90(10):1470-1480. DOI 10.3732/ajb.90. 10.1470

Kholina A.B., Kozyrenko M.M., Artyukova E.V., Sandanov D.V., Andrianova E.A. Phylogenetic relationships of the species of Oxytropis DC. subg. Oxytropis and Phacoxytropis (Fabaceae) from Asian Russia inferred from the nucleotide sequence analysis of the intergenic spacers of the chloroplast genome. Russ. J. Genet. 2016;52(8):780793. DOI 10.1134/S1022795416060065.

Kholina A., Kozyrenko M., Artyukova E., Sandanov D., Selyutina I., Chimitov D. Plastid DNA variation of the endemic species Oxytro- pis glandulosa Turcz. (Fabaceae). Turkish J. Bot. 2017;42(1):38-50. DOI 10.3906/bot-1706-11.

Leigh J.W., Bryant D. PopART full-feature software for haplotype network construction. Methods Ecol. Evol. 2015;6(9):1110-1116. DOI 10.1111/2041-210X.12410.

Li X., Yang Y., Henry R.J., Rossetto M., Wang Y., Chen S. Plant DNA barcoding from gene to genome. Biol. Rev. 2015;90:157-166. DOI 10.1111/brv.12104.

Librado P., Rozas J. DnaSP v5 a software for comprehensive analysis of DNA polymorphism data. Bioinformatics. 2009;25(11):14511452.

Lu P., Gao L., Jin F., Enhebayaer E. Molecular phylogeny of 10 species of Oxytropis based on psbA-trnH sequences. Acta Bot. Yunnanica. 2014;3:279-284. DOI 10.1093/bioinformatics/btp187. DOI $10.7677 /$ ynzwyj201413135.

Malyshev L. Diversity of the genus Oxytropis in Asian Russia. Turczaninowia. 2008a;11(4):5-141.

Malyshev L.I. Phenetics of the subgenera and sections in the genus Oxytropis DC. (Fabaceae) bearing on ecology and phylogeny. Contemp. Probl. Ecol. 2008b;1(4):440-444. DOI 10.1134/ S1995425508040073

National Center for Biotechnology Information. U.S. National Library of Medicine, Rockville Pike, 1988. https //www.ncbi.nlm.nih.gov. Accessed 2 August 2017.

Saitou N., Nei M. The neighbor-joining method. A new method for reconstructing phylogenetic trees. Mol. Biol. Evol. 1987;4:406-425.

Tamura K., Stecher G., Peterson D., Filipski A., Kumar S. MEGA6 Molecular Evolutionary Genetics Analysis Version 6.0. Mol. Biol. Evol. 2013;30(12):2725-2729. DOI 10.1093/molbev/mst197.

Techen N., Parveen I., Pan Z., Khan I. DNA barcoding of medicinal plant material for identification. Curr. Opin. Biotechnol. 2014;25:103110. DOI 10.1016/j.copbio.2013.09.010.

Tekpinar A., Erkul S.K., Aytac Z., Kaya Z. Phylogenetic relationships among native Oxytropis species in Turkey using the $\operatorname{trn} \mathrm{L}$ intron, trnL-F IGS, and trnV intron cpDNA regions. Turkish J. Bot. 2016; 40(5):472-479. DOI 10.3906/bot-1506-45.

The Red Book of the Republic of Kazakhstan. Almaty: ArtPrint XXI, 2014.

Turuspekov Y., Abugalieva S. Plant DNA barcoding project in Kazakhstan. Genome. 2015;58(5):290.

Turuspekov Y., Abugalieva S., Ermekbayev K., Sato K. Genetic characterization of wild barley populations (Hordeum vulgare ssp. spontaneum) from Kazakhstan based on genome wide SNP analysis. Breed. Sci. 2014;64(4):399-403. DOI 10.1270/jsbbs.64.399.

Turuspekov Y., Adams R.P., Kearney C.M. Genetic diversity in three perennial grasses from the Semipalatinsk nuclear testing region of Kazakhstan after long-term radiation exposure. Biochem. Syst. Ecol. 2002;30(9):809-817. DOI 10.1016/S0305-1978(02)00021-2.

White T.J., Bruns T., Lee S., Taylor J. Amplification and direct sequencing of fungal ribosomal RNA genes for phylogenetics. PCR Protocols: a Guide to Methods and Applications. 1990;18(1): 315-322. 